\title{
Calle y calles de Brasil: imágenes, lecturas y etnografías
}

\author{
Urpi Montoya Uriarte \\ (Universidad Federal de Bahía, Brasil)
}

Recibido: $18 / 3 / 2015$

Aprobado: 4/6/2015

\begin{abstract}
Resumen. En este artículo me propongo reflexionar acerca de la calle de la ciudad contemporánea, movida por una pasión por lo urbano y una formación en antropología. La vida de las calles nos dice mucho sobre el tipo de ciudad en las que se encuentran. Sin embargo, son pocos los esfuerzos para captarla en sus detalles, particularidades, singularidades. Como urbanistas, parecemos conformarnos con las imágenes mentales que tenemos de ellas y como intelectuales, muchas veces, nos contentamos con reproducir teorías ya consagradas sobre las características y el papel de las calles en nuestras sociedades. Así, estas líneas comienzan discutiendo algunas imágenes mentales que gran parte de los habitantes de las ciudades modernas tenemos en torno a la calle. Expongo después algunas propuestas de lectura que consagrados intelectuales brasileños hicieron sobre la calle en ese país.

Palabras clave: ciudad / calle / etnografía urbana / historia urbana / imágenes mentales
\end{abstract}

\section{Street and Streets of Brasil: Images, Readings and Ethnography}

Summary. Driven by a passion for urban and a training in anthropology, in this article I reflect on the street in the contemporary city. Street life tells us much about the kind of city one it belongs to. However, there only few efforts have been carried out in order to grasp the street's details, features and singularities. As planners, we seem content with the mental images we have of streets and often, as intellectuals, we are content to reproduce already established theories about the nature and role of streets in our societies. Thus, these lines begin discussing some of the mental images that many of the inhabitants of modern cities have about the street. Later, I expose readings of renowned Brazilian intellectuals about the street in Brazil.

Key words: city / street / urban ethnography / urban history / mental images

1 Traducción de Rodrigo Montoya Rojas. 


\section{Introducción}

$\mathrm{J}$ ane Jacobs decía: “Qué es lo primero que nos viene a la mente al pensar en una ciudad? Sus calles" (1973, p. 33). Y como ella misma lo dijera, pensar en la ciudad es pensar en la calle. Pero ¿qué es lo que viene exactamente a la mente cuando pensamos en la calle? De hecho, pueden surgir algunas imágenes mentales, generalmente derivadas de otras imágenes (cinematográficas, literarias); pueden aparecer también algunas lecturas o interpretaciones de reconocidos intelectuales sobre las características de la calle en un determinado país; o descripciones detalladas de calles particulares de una ciudad.

En este artículo reflexiono sobre algunas imágenes de la calle, algunas propuestas interpretativas brasileñas acerca de la calle en este país y algunas descripciones etnográficas de calles particulares en Brasil. El objetivo es poner de relieve la contribución de las investigaciones empíricas que describen calles específicas y permiten des-construir, relativizar o enriquecer imágenes simplificadoras y lecturas demasiado amplias para captar o leer lo que realmente ocurre en las calles.

\section{Imágenes}

En esta sección abordaré algunas imágenes mentales recurrentes en torno a la ciudad ${ }^{2}$. Las imágenes mentales se distinguen de las imágenes concretas o materiales que se pueden captar a través de los sentidos (Joly, 1994). Son aquellas representaciones inmateriales inmediatas que, a pesar de que no tenemos conciencia de su origen, son bastante nítidas, hasta el punto de tener la impresión de "verlas" en nuestras mentes.

La imagen mental de la calle es recurrentemente una imagen de tránsito (de personas, cosas, bienes, vehículos, servicios, etc.) y de una multitud. La imagen de movimiento y flujo parece coincidir con lo que el capitalismo ha promovido en muchas calles del mundo al convertirlas en vías de circulación "para el tránsito, para el transporte de la mayor carga posible (persona, animal o cosa) por la mayor distancia posible, en el menor tiempo posible, sin obstrucciones ni distracciones" (Christlieb, 2004, p. 29).

En la segunda década del siglo $X X$, Le Corbusier ${ }^{3}$ convirtió esta imagen de tránsito en una propuesta urbanística. En el "siglo de la máquina", escribió

2 Las imágenes mentales de las que trataré en esta sección derivan de la verbalización y diseños de mis alumnos del curso Antropología Urbana, que dicto en la Facultad de Filosofía y Ciencias Humanas de la Universidad Federal de Bahía, Brasil.

3 Le Corbusier, pseudónimo de Charles-Edouard Jeaneret-Gris, fue un arquitecto que tuvo una influencia fundamental en el desarrollo del urbanismo funcionalista. Fue promo- 
el arquitecto francés, las calles debían ser consideradas como "máquinas para circular". Sin poesía y sin nostalgia, él defendió la necesidad de repensar la función de las ciudades y del trazo de sus calles para adaptarse a la nueva e intensa vida industrial y comercial: "la calle ya no es sólo la tierra firme sino máquina para circular, un aparato circulatorio" (Le Corbusier, 1962, p. 77). Estaba convencido de que en las nuevas zonas urbanas o en los viejos centros demolidos, la geometría y la racionalidad deberían guiar la construcción de edificios, puesto que el estado del espíritu humano es geométrico, ortogonal, recto:

El hombre que traza rectas demuestra que ha recobrado el dominio de sí mismo, que ingresa al orden. La cultura es un estado de espíritu ortogonal. No se crean rectas deliberadamente. Se llega a la recta cuando se tiene fuerza bastante, armas bastantes y lucidez bastante como para querer y poder trazar rectas (Le Corbusier, 1962, pp. 28-29).

En el primer encuentro con mis alumnos de Antropología Urbana suelo pedirles que dibujen una imagen de la ciudad. Gran parte de los dibujos presentan ciudades planas, de vías rectas, amplias avenidas y parques y plazas cuadriculadas. Llama la atención el contraste de esta imagen con la ciudad de Salvador donde viven, una ciudad compuesta principalmente por colinas y valles estrechos, calles curvas, con escasos parques o plazas. Pocos de los estudiantes que se matriculan en el curso de Ciencias Sociales han leído o escuchado hablar de Le Corbusier. Desafortunadamente, en consecuencia, no es necesario haberlo leído para compartir con él la imagen de la calle como un espacio recto para una circulación intensa, de vías o "caminos para el paso humano, de vehículos y de mercancías, rodeado por edificios o terrenos baldíos, que integran el escenario físico de las ciudades" (Frehse, 2011, p. 15).

Reducida a una vía de paso, la calle sería una forma sin contenido o una forma cuyo contenido no interfiere en ella. Era esta la imagen que la activista Jane Jacobs quería combatir cuando se opuso a la construcción de la carretera Lower Manhattan, idealizada por Robert Moses en Soho, en la Nueva York de la década de 1950. Para ella, "las calles sirven para muchas cosas, aparte de soportar a los vehículos de paso; y las aceras de las ciudades - parte de las calles destinadas a los peatones- tienen muchos otros usos además de soportar

tor del Congreso Internacional de Arquitectura Moderna (CIAM), en 1929, y uno de sus principales protagonistas. Hizo proyectos para muchos países, incluso un esbozo para la reforma de Río de Janeiro a fines de la segunda década del siglo pasado. Escribió varios textos, entre los que destacan La ciudad del futuro (1924) y La ciudad radiante (1925). 
el caminar de los peatones" (Jacobs, 1973, p. 33). El éxito de su movilización y una serie de conferencias que ofreció le permitieron sistematizar sus ideas en el libro Death and life of great american cities (Muerte y vida de las grandes ciudades, 1973), publicado en 1961. Al defender las aceras y oponerse a su reducción para favorecer el automóvil, y en contra de la segregación de usos y los barrios de baja densidad, Jacobs se convirtió en una de las voces más importantes contra el funcionalismo urbanista de mediados del siglo XX. Hablando de su experiencia como residente de Greenwich Village, propuso la calle como lugar de contactos, de todo tipo, como describe en las siguientes líneas:

Personas que se paran en un bar para beber una cerveza, charlan con los tenderos o el quiosquero de la esquina, confrontan opiniones con los otros clientes de la panadería y saludan de viva voz a los dos mozalbetes que beben limonada a la puerta del jardincillo de su casa, vigilan el alboroto de las niñas que esperan la hora de almorzar o cenar, sermonean a los niños en general, cambian impresiones con el droguero sobre las perspectivas de un nuevo empleo y compran a préstamo en la ferretería por valor de un dólar, contemplan y admiran el bebé recién nacido de los vecinos de la esquina y se alivian o compadecen por la manera de avejentarse que tiene la chaqueta comprada el mes pasado (Jacobs, 1973, p. 60).

De modo que, además de ser ruta de comunicación desde un punto a otro en un plano geométrico, la calle es también un espacio de contactos; es decir, de relaciones. Sin embargo, Jacobs advertía que para que una calle mantenga esta función, era necesario que en ellas se desenvolviesen muchas y diversas actividades. Para ella, la muerte de las grandes ciudades de Estados Unidos era consecuencia de la muerte de las calles promovida por los reformadores urbanos funcionalistas, para quienes la diversidad (de usos, funciones, usuarios) equivalía a caos y desorden.

Pero volvamos a las imágenes, esta vez, del hombre que transita por las calles. Se imagina al transeúnte como un ser solitario, silencioso, apresurado, mirando constantemente el reloj o el suelo, evitando cualquier contacto físico o visual. La imagen es la de un hombre solo, casi aplastado por la multitud que transita a su lado. Algunos escritores del siglo XIX plasmaron esta imagen. Entre ellos podemos mencionar a Charles Baudelaire y Edgar Allan Poe. En el poema Pérdida de la aureola, cuya trama se desarrolla en un caótico bulevar de París - de polvo, barro, con carruajes y peatones-, Baudelaire describe al transeúnte que se convertiría en arquetipo y que Marshall Berman resumió brillantemente como el "peatón lanzado en el torbellino del tráfico de la ciudad moderna, un hombre solo, luchando contra un aglomerado de masa y de energía pesadas, veloces y mortíferas" (Berman, 1989, p. 154). En El hombre de la multitud, cuento escrito en la primera mitad del siglo XIX, Poe 
(1840) describe con detalles la enorme diversidad de gente que se mueve en gran número en las calles del centro de Londres (en ese momento, la ciudad más poblada de Europa). En estas "hordas" y "turbas" de gente, nadie habla, los gestos son ritualistas, cada uno está solo. Llama la atención del narrador un hombre que no deja de caminar en estas calles apiñadas de gente, que no utiliza las calles para ir a algún lugar, sino que da vueltas y vueltas. El narrador llega a la conclusión de que el "hombre de la multitud" aun estando solo, se siente acompañado.

Acompañado, próximo y sin embargo distante. Según George Simmel (1976), la proximidad física existente en las calles llenas de gente motivaba en los transeúntes el desarrollo de una distancia subjetiva. Simmel fue un apasionado por detectar las transformaciones que las grandes ciudades estaban promoviendo en sus habitantes a fines del siglo XIX. Entre ellas destacó la racionalización, intelectualización, preocupación por el cálculo, simetría (expresión estética de la voluntad de racionalizar), énfasis en el presente (moda), inestabilidad y movimiento (de los contenidos de la existencia, de las identidades).

En su artículo "La metrópoli y la vida mental", escrito en 1902, el sociólogo berlinés afirma que la calle moderna creó un nuevo tipo de hombre que en ella transita, un hombre con una actitud nueva que él llamó blasé. Esta actitud está directamente rela- cionada con la economía monetaria que produjo el debilitamiento del "poder de discriminar": de ese modo el hombre moderno ve todo su contorno como uniformemente plano, opaco, descolorido. Lo que este autor nos propone es que más que una pérdida de la capacidad de distinguir se trata del surgimiento de una indiferencia ante las diferencias, una nueva sociabilidad fundada en la distancia (Joseph, 2002). Simmel veía en esta actitud una reacción racional de autopreservación: frente a la proximidad física era necesario desarrollar una distancia mental que se traduciría en una actitud de indiferencia y frialdad. El hombre que transita en las calles modernas es, pues, para Simmel, un hombre conscientemente indiferente, desinteresado, distante, reservado, cínico, un ser frío que siente repulsión por el contacto más próximo con los otros.

Cuando discuto el texto "La metrópoli y la vida mental" con mis alumnos, me llama la atención la identificación que demuestran con la actitud blasé. En efecto, el transeúnte blasé forma parte de las imágenes que la mayoría de ellos tiene del hombre que circula por las calles de las grandes ciudades.

\section{Lecturas brasileñas}

Comencemos esta sección con algunas descripciones históricas de la calle en Brasil. Refiriéndose a las calles del siglo XIX, Gilberto Freyre escribió que se trataba de "calles sucias, pen- 
dientes inmundas, por donde casi sólo pasaban a pie negros que vendían su jornada, muchachos volando cometas, mujeres públicas" (Freyre, 2004, p. 269). Tan mal era vista la calle que a menudo se practicaba "la costumbre de los hombres de orinar en las calles; y de lanzar a las calles la orina descompuesta de las casas o sobrados ${ }^{4} \mathrm{sin}$ patio" (Freyre, 2004, p. 316). Luego de analizar las fotografías del centro de la ciudad de São Paulo, en la mitad de ese mismo siglo, Fraya Frehse concluyó: "La calle era un lugar donde permanecían los sectores menos pudientes de la población -esclavos, libres o libertos, brasileños o inmigrantes- y por donde pasaban eventualmente otros grupos pudientes" (Frehse, 2005, p. 33, cursivas de Frehse). Según el arquitecto Murillo Marx (1989), en el período colonial, con excepción de los días festivos, las calles eran "un escenario de actividades muy mediocres", y por eso eran "estrechas las calles y pocos los largos ${ }^{5}$ y jardines" (Marx, 1989, pp. 7-8). Incluso, a finales del siglo XIX esa fue la impresión que las calles dejaron: "la monotonía y desolación de lo cotidiano fueron abundantemente reporta- das entonces por cronistas extranjeros como Alfonso Lomonaco. Poca gente en las calles, algunas en las ventanas, muchas -casi toda- dentro de sus casas" (Marx, 1989, pp. 78, 80).

Dos breves informaciones más. Las calles más importantes de las ciudades brasileñas -calles derechas, como se les llamaba- eran las que unían un monumento (generalmente religioso) a otro. Las plazas, que eran el elemento central y primero en la formación de las ciudades de América conquistadas por los españoles- eran pocas aquí; en lugar de las plazas lo que hubo fueron largos, alargamiento de algunas calles estrechas generalmente en la parte frontal de las iglesias, terrenos dejados libres para el paso de las procesiones.

Presento ahora algunas lecturas que tratan de comprender y explicar este panorama concreto de las calles brasileñas: calles sucias, poco utilizadas en la vida cotidiana, con usos más sagrados que mundanos; lugar de pobres, de gente mal considerada, donde había más largos que plazas propiamente dichas.

Murillo Marx leyó este escenario como una consecuencia del predo-

4 Sobrado es una casa de tres pisos o más, con un área relativamente grande. A diferencia de las "casonas" hispánicas, los sobrados no tienen un patio interno central, pareciéndose más a un edificio que a una casa. En el Brasil colonial, los grandes propietarios de tierras y los más importantes comerciantes vivían en sobrados.

5 Los largos eran espacios urbanos más o menos amplios sin construcciones. Localizados generalmente al frente de las iglesias, estos vacíos facilitaban la aglomeración en días de procesión católica. Así, los largos se distinguen de las plazas, cuya función original era tanto civil como religiosa. 
minio de las funciones religiosas en la composición del espacio urbano brasileño, lo que a su vez sería consecuencia de la ausencia en las colonias portuguesas de una clara división entre el poder temporal y el poder espiritual (hecho que no ocurre en las colonias españolas, prueba de ello sería el primero de los nueve libros que conforman la Recopilación de leyes de los Reynos de Indias...). Esa falta de separación clara condujo a la formación de un territorio en el cual "las reglas de la Iglesia, a lo largo de las colonias, fueron seguidas más fielmente que las del Estado" (Marx, 1989, p. 20). En contraste con la legislación eclesiástica (véanse las Constituiçoens primeyras do Arcebispado da Bahia), la legislación civil sobre el uso de las calles era muy general: había mucha claridad para edificar un templo, pero eran tímidas o casi inexistentes las normas para determinar la disposición de las calles o la parcelación del suelo urbano. De hecho, para la Iglesia y para el Estado, las procesiones eran mucho más importantes que las calles y su pavimentación. De este modo, se impusieron en Brasil los usos religiosos y festivos sobre los usos mundanos y cotidianos.

Vemos así el estado permanente de abandono, suciedad, de ninguna pavimentación o pobre pavimento de las calles a lo largo de cuatro siglos. La falta de recubrimiento o su precariedad reflejan bien el concepto que se tenía de las calles, su poco uso cotidiano, la correspondencia con su ámbito limitado. Eran los eventos fes- tivos, sobre todo las procesiones, los que suponían los mayores cuidados, al menos hasta que otras necesidades más mundanas se impusiesen con fuerza (Marx, 1989, p. 164).

Con respecto a las normas sobre el uso del espacio público, lo mundano logró imponerse sobre lo sagrado solo en el siglo XIX. La creación, decoración y cuidado de los espacios públicos, como parques y jardines (con sus fuentes y monumentos), únicamente fueron posibles a mediados de ese siglo. Del mismo modo, solo en la tardía fecha de 1886 se codificaron las ordenanzas municipales de la ciudad de São Paulo: horarios de uso de las calles para los esclavos, el paradero de los coches de carga, el entrenamiento de los cocheros y animales de carga, la anchura de las calles, la forma cuadrada de las plazas, la licencia para la apertura de calles o edificación de casas, etc. (Marx, 1989, p. 146).

En Raíces del Brasil, Sérgio Buarque de Holanda se refiere también al contraste entre las ciudades españolas y portuguesas en el Nuevo Mundo. Las primeras fueron numerosas y ordenadas; la plaza delimitaba claramente el principio y el centro de la ciudad. En contraste,

la ciudad que los portugueses construyeron en América no es un producto mental, no alcanza a contradecir el marco de la naturaleza, y su silueta se confunde con la línea del paisaje. Ningún rigor, ningún método, ninguna previsión, siempre este significativo abandono que la palabra desleixo [ne- 
gligencia] expresa, palabra que el escritor Aubrey Bell consideró tan típicamente portuguesa como saudade [nostalgia], y que a su juicio implicaba menos falta de energía que una íntima convicción de que "no vale la pena"... (Buarque de Holanda, 1994, p. 76).

Un raso y tosco realismo estaría en la base de la escasa atención prestada por los portugueses a la obra urbana en Brasil. Este realismo los habría llevado a hacer preguntas como estas: ¿si nuestro modelo de colonización es costero y de puestos comerciales para qué invertir en la legislación de las ciudades?, ¿si el orden social no está en peligro, para qué convertir el espacio en un modelo de orden? Según el sociólogo e historiador paulista la situación de los españoles era otra; para ellos, la codificación del espacio se hizo absolutamente necesaria:

La furia centralizadora, codificadora, uniformizadora de Castilla, que tiene su expresión más nítida en el gusto por los reglamentos minuciosos -capaz de ejercerse como ya se ha destacado, incluso en el trazado de ciudades coloniales- viene de un pueblo enteramente desunido y bajo permanente amenaza de desagregación. El pueblo castellano tuvo necesidad de luchar dentro de sus propias fronteras peninsulares con los aragoneses, los catalanes, los vascos y los moros, no sólo hasta 1492 sino hasta 1611 (Buarque de Holanda, 1994, p. 82).
Y así fueron surgiendo y creciendo las ciudades en Brasil, obra más espontánea y ordinaria que mental o utópica. La espontaneidad explicaría las calles tortuosas, estrechas, descuidadas, sin legislación para ordenarlas.

Gilberto Freyre explica de otra manera la falta de atención, el descuido y la devaluación de la calle. En su opinión, estas características son el resultado del peso de la casa en Brasil (casa entendida en sus diversas formas: la casa grande o casa hacienda, los barracones de esclavos, los mucambos ${ }^{6}$ ). Como señala Roberto da Matta en su presentación de la decimoquinta edición del libro Sobrados y mucambos, los valores en la formación de Brasil emanaban de la casa, vista por el autor pernambucano como "un campo del que irradiaban modelos de comportamiento, signos de autoridad, símbolos $\mathrm{y}$, sobre todo, relaciones sociales. Todo un sistema de vida y de dominación" (Da Matta, 2004, p. 17).

El predominio de la casa sobre la calle, en Brasil, se explica por el sistema patriarcal que prevaleció aquí y se reforzó hasta bien entrado el siglo XIX. La sociedad patriarcal brasileña era una sociedad de familias extensas que dominaban grandes espacios y numerosas personas (mujeres, capellanes, ahijados, sirvientes, esclavos, etc.). Los

6 Mucambo es el nombre dado a las edificaciones frágiles y precarias, construidas artesanalmente. Un equivalente en español podría ser choza. Optamos por mantener en el texto la palabra en portugués. 
espacios dominados por estas familias extendidas eran contradictorios, jerárquicos $\mathrm{y}$, al mismo tiempo, complementarios y cercanos: incluyen la casa hacienda y el barracón de esclavos (senzala), los negros y los blancos, los hombres y las mujeres, las esposas y las concubinas, los amos y los esclavos, los descendientes legítimos y los ilegítimos. Eran lugares donde convivían la intimidad y la violencia, el despotismo y la inclusión (Freyre, 1994).

En el sistema patriarcal, la casa era un espacio prácticamente autosuficiente del que no salían quienes estaban dentro y no entraban quienes estaban fuera. Cuando en el siglo XIX este sistema se trasladó del campo a la ciudad, la casa grande se convirtió en un sobrado, que trató de mantenerse igualmente cerrado ${ }^{7}$. Así, en las ciudades los sobrados se volvieron enemigos de las calles. Los patios traseros convertidos en huertas, en la medida de lo posible y mientras pudieron, intentaron conservar la economía privada, doméstica, que aislaba la casa en su propio mundo. Destaquemos algunos elementos físicos de los sobrados que prueban su enemistad con la calle: su localización lejos de esta, la poca presencia de patios delanteros, la ausencia de balcones en los pisos superiores. Por estas razones, según Freyre (2004, p. 272), las casas con patios delanteros supusieron una condescendencia del sistema patriarcal con la ciudad antipatriarcal.

A comienzos del siglo XIX, John Luccock visitó Río de Janeiro y percibió su gramática social: el patio detrás de la casa era el lugar más aislado de la calle y, por ello, era el lugar de reunión de la familia. El patio delantero (próximo a la fachada) era el límite al que los extraños podían llegar, porque el interior de las casas estaba absolutamente vedado para ellos, siendo reser-

7 Según Freyre (2004, p. 299), los sobrados se distinguían tanto de las "casas de un piso con puerta y ventana" como de los "sobrados degradados en tugurios". A su vez, las casas de un piso y sobrados tugurizados se distinguían de los mucambos de paja y barro. Los sobrados propiamente dichos se distinguían entre sí por los materiales usados, pues los había de materiales más "nobles" ("piedra, cal, adobe, teja, madera de ley, rejas de fierro") y menos "nobles". Se diferenciaban también por el número de pisos. En Recife, varios sobrados llegaban a tener seis pisos: en el primero se localizaban el almacén comercial y el cuarto de esclavos; en el segundo, la administración comercial; en el tercero, la sala de visitas; en el cuarto, los dormitorios; en el quinto, la sala de comer, y en el sexto, la cocina. Otro criterio de distinción era su localización: los construidos en la cumbre de las colinas tenían mucho más prestigio que aquellos construidos abajo, en el valle de las colinas; así como los construidos en terreno plano valían mucho más que los construidos en la pendiente (vistos frontalmente, estos parecían ser casas de un piso pero observados lateralmente eran casas de varios pisos que acompañaban el declive de la colina, llegando algunos hasta los propios valles mientras otros colindaban con barrancos o precipicios). 
vado solo a las mujeres. En los jardines del fondo las mujeres podían transitar, "como una débil compensación por su cautiverio" (Luccock, en Da Matta, 1985, p. 44). En situaciones rituales -visitas anunciadas, personas invitadas- el espacio para los extraños era la sala (llamada sala de visitas).

El antropólogo Roberto Da Matta, que se declaró intelectualmente deudor de Freyre, tiene su propia lectura sobre el porqué en Brasil la calle es en general sucia y violenta, tan mal considerada. Para él, más allá de la oposición casa grande y barracones de esclavos, o sobrados y mucambos, hay otra oposición tan o más grande en Brasil: la casa y la calle. Da Matta heredó de Freyre la visión de considerar esos espacios mucho más que espacios físicos (un lugar de residencia o una vía de circulación); en Brasil la casa y la calle son lugares de significado, de valorización, de evaluación ética: "son entidades morales, esferas de acción social, provincias éticas dotadas de positividad, dominios culturales institucionalizados y, por eso, capaces de despertar emociones, reacciones, leyes, oraciones, músicas, imágenes estéticamente moldeadas e inspiradas" (Da Matta, 1985, p. 12).

El espacio de la casa -que puede ser la propia casa o incluir una vecindad e incluso un barrio- representa el universo de personas con sus nombres propios, los lazos de familia, de sangre, de igualdad; representa la lealtad personal, la simpatía, la bondad, la hospitalidad; un lugar donde deben evitarse las disputas, o mantenerse dentro de las cuatro paredes ("los trapos sucios se lavan en casa", dice el refrán); un espacio tranquilo de descanso.

"Sufrir en la calle de la amargura" y "estar en el ojo de la calle" son algunas frases que sintetizan la idea de calle como un espacio sin clemencia. Estar en la calle es sufrir, es estar solo, desamparado. La calle es, pues, el espacio que representa la ausencia de parientes, de familiares, de amigos; es el espacio de los individuos anónimos: de cada uno para sí, del "sálvese quien pueda"; el espacio de la lucha por sobrevivir; el espacio de la ley, impersonal, que no toma en cuenta las situaciones particulares y, por eso, un espacio de imposición, defectuoso, que se confunde con la indiferencia y la insensibilidad. El espacio de la calle es también movimiento, fluidez, peligro:

Hasta hoy la sociedad parece fiel a su visión interna del espacio de la calle como algo lleno de movimiento, propicio a desastres y robos, donde las personas pueden ser confundidas con indigentes o tomadas por lo que no son. Nada peor para cada uno de nosotros que ser tratados como "gente común", como "gentuza que no tiene donde caerse muerta" (Da Matta, 1985, p. 50).

De este modo, casa y calle no son espacios físicos concretos sino formas de valorización y códigos:

el código de la casa (fundado en la familia, la amistad, la lealtad, en la persona y el compadrazgo) y el código de la calle (basado en leyes universales, en una vieja burocracia profunda- 
mente arraigada entre nosotros, y en un formalismo jurídico-legal que llega casi hasta el absurdo) (Da Matta, 1985, p. 20).

Estos códigos se aplican flexiblemente a diferentes espacios. Así, en algunas áreas y situaciones prevalece el prisma personal y familiar, en otros, la impersonalidad y la ley. En algunos discursos, el ángulo de la casa prevalece con la persona y la intensidad emocional; en otros, es el ángulo de la calle, con su anonimato y rigidez. La casa y la calle, es decir, los códigos de la casa y de la calle, son pues formas de ordenar la realidad, de guiar la experiencia social, de modo que el comportamiento de los brasileños en la calle sería guiada por el código de la calle:

Arrojamos la basura fuera de nuestra vereda, puertas y ventanas; no obedecemos las normas de tráfico, incluso somos capaces de depredar los bienes comunes, de victimizar a la cosa común usando el famoso y no analizado argumento de que todo lo que está fuera de nuestra casa es un "problema del gobierno". La vergüenza y el desorden en la calle no es asunto nuestro, sino del estado (Da Matta, 1985, pp. 16-17).

Es importante destacar que en el esquema de Da Matta, así como en el de Freyre, la casa y la calle no solo se oponen, sino que también se complementan. Es fundamental estudiar aquel " $y$ " que conecta a la casa con la calle, agrega el antropólogo. Hay subespacios que cumplen esta función de relacionar espacios: dentro de la casa, por ejemplo, el corredor, el balcón, la sala de estar y las ventanas. Hay también momentos, y entre ellos la hora de la fiesta es para Da Matta especialmente importante, pues permite rehacer la unidad de los contrarios. En la fiesta, "la calle y la casa se convierten en espacios contiguos, reunidos por una convivencia temporalmente utópica de espacios divididos rígidamente en el mundo de todos los días" (Da Matta, 1985, p. 53).

En la década de 1980, el antropólogo José Guilherme Magnani propuso la categoría de "pedazo" para hablar de esa " $y$ " que liga la casa y la calle. El pedazo, escribió, es ese

espacio intermediario entre lo privado (la casa, el hogar) y lo público, donde se desenvuelve una sociabilidad básica, más amplia que la fundada en los lazos familiares, pero más densa, significativa y estable que las relaciones formales e individualizadas impuestas por la sociedad (Magnani, 1996, p. 32).

El pedazo puede ser un bar, una esquina, una calle; es decir, un espacio físico. Pero no es solo eso: es una sociabilidad, una forma de relacionarse que puede ser llevada de un lugar a otro. Es, por lo tanto, una categoría que describe una forma particular de sociabilidad, una en la que todos se conocen, donde se comparten códigos comunes, gustos, pautas, valores, hábitos de consumo, modos de vida semejantes.

En la propuesta de Magnani habría, entre la sociabilidad basada en nuestros valores de lo íntimo, familiar, conocido y de consideración, y la sociabilidad basada en lo público, 
impersonal, desconocido y en la ley, una tercera sociabilidad, intermediaria, que se desarrolla en ciertos lugares de la calle, que sería más abierta que el espacio fundado en los lazos familiares de la casa, pero que no llegaría a alcanzar la formalidad y la impersonalidad propias de la calle. La pregunta es, ¿en qué lugares específicos de la calle y en qué tipo de calles específicas se desenvuelve esta tercera sociabilidad?, ¿por qué en ciertas calles sí y en otras no? Para responder a estas preguntas es indispensable descender del nivel o escala de lo general al nivel o escala de lo micro, de la calle concreta.

\section{Calles con alma}

Como hemos visto hasta ahora, la calle de las imágenes mentales es diferente a la calle como categoría analítica utilizada para leer la sociedad brasileña. Las imágenes nos muestran calles de transeúntes solitarios, calles llenas de personas y objetos en movimiento. La calle como categoría se refiere a códigos éticos y de sociabilidad que asociamos con ella y que colocamos en la práctica en diferentes espacios que valoramos como "calle", en oposición a otro primer código que le sirve de contraste, la ética y sociabilidad de la casa. Sin embargo, cuando pasamos por una calle y nos detenemos en ella, cuando dejamos de hablar en la calle en abstracto y en general, y pasamos a referirnos a calles concretas y singulares, apare- cen otras calles, calles con alma, diría João do Rio (2008, p. 29).

"Amo la calle". Así comenzaba una conferencia el famoso cronista carioca. João do Rio amaba las calles porque veía en ellas mucho más que una "hilera de fachadas, por donde se camina" (Rio, 2008, p. 29) o un dominio cultural revelador de la sociedad brasileña. Para él, la calle es un ser vivo, y como tal, cada una tiene su individualidad, su alma, su filosofía:

Hay calles honestas, hay calles ambiguas, calles siniestras, calles nobles, delicadas, trágicas, depravadas, puras, infames, calles sin historia, calles tan viejas que son suficientes para contar la evolución de una ciudad entera, calles guerreras, revoltosas, temerosas, spleenéticas [agitadas], snobs, calles aristocráticas, calles amorosas, calles cobardes que permanecen sin una gota de sangre ... (Rio, 2008, p. 34).

No hay, por lo tanto, una calle en Brasil. Hay varias, muchas calles en cada ciudad, cada una con su alma. Él recorrió las calles de la ciudad de Río de Janeiro buscando sus almas. Además de las fantásticas descripciones de ellas, João do Rio nos legó una propuesta de comprensión de sus singularidades: el alma de una calle se desprende de sus usos, de sus usuarios, de su historia.

La historia tiene en João do Rio un fuerte peso en la construcción y mantención del alma de una calle. Veamos el caso de la calle de la Misericordia. Nuestro autor se refiere a ella como "lamentable, tan angustiada, franca y 
verdadera en su dolor" precisamente por cargar en su alma el peso de su historia: esta fue la primera calle de la ciudad y por lo tanto el primer palco para ver el sufrimiento de "indios golpeados, de negros presos en cadenas, dominio ignorante y bestial (...) sollozo del golpeado, primer esfuerzo de una porción de infelices" (Rio, 2008, p. 35). Similar es el caso de la calle Playita, que a pesar de las reformas, mantiene "una impresión de vago horror (...), porque siempre fue mala, porque fue el Aljube [la cárcel]; allí padecieron los negros de los tres primeros trapiches de sal, porque también allí la Horca propagó la muerte!" (Rio, 2008, p. 36). Pero la historia no lega solo sufrimiento en ciertas calles. Puede dejar también sutileza y humor, como en el caso del Largo del Rocío, cuya alma poco seria deriva, para el cronista, del hecho de haber sido el escenario histórico donde don Pedro I "mostró el Acta de la independencia, simulando haber dado un grito que nunca dio. Así es: no hay un sujeto más divertido y menos serio que el viejo ex Largo del Rocío" (Rio, 2008, p. 38).

Los usuarios o practicantes ${ }^{8}$ de una calle también pueden marcar su alma. La calle del Oidor tiene para João do Rio el alma de la frivolidad, porque los sectores dominantes de la capital la convirtieron en el escenario principal para exhibirse. Adquiriendo el alma de quienes practican el espacio, esa calle se convirtió en el "infierno de la pose, de la vanidad y de la envidia" (Rio, 2008, p. 34).

Los usos o prácticas pueden también marcar el alma de las calles, como en el caso de aquellas próximas a los puertos, que él llama "calles recorridas con la visión de otros horizontes". Ellas adquieren el alma del mar, "la perfidia de los océanos, la miseria de las inmigraciones y el vicio del mar y de las colonias" (Rio, 2008, p. 38). El uso residencial también define a algunas calles, como las del barrio de Santa Teresa: calles domésticas, íntimas, donde todos saben de todo, donde ningún extraño pasa desapercibido.

Al poseer un carácter, que surge de su historia, sus usos y sus usuarios, la calle pasa a moldear a los tipos humanos que la frecuentan. Esta es una segunda idea interesante de João do Rio: "En las grandes ciudades la calle comienza a formar su tipo, a dar forma a la moral de sus habitantes, a inocularles misteriosamente gustos, costumbres, hábitos, modos, opiniones políticas" (2008, p. 41). El autor llega hasta a predicar un determinismo de la calle: “¡Oh! sí, la calle produce al individuo, nosotros lo sentimos. Un

8 Mantenemos aquí la expresión "practicantes" del espacio propuesta por Michel de Certeau (2009), para enfatizar que los espacios son también moldeados, definidos, transformados por aquellos que los usan. 
ciudadano que había pasado la mitad de la existencia en la calle Palo de Fierro no puede acostumbrarse nunca a la calle Marqués de Abrantes" (Rio, 2008, p. 42). Más adelante reiteró: “En este elogio, frívolo tal vez, consideré a la calle como un ser vivo tan poderoso que puede cambiar insensiblemente al hombre y convertirlo en su perpetuo esclavo delirante" (Rio, 2008, p. 51).

Sí creo que las calles tienen alma, si entendemos por ella un fuerte rasgo distintivo, que perdura en el tiempo, que se obstina en permanecer a pesar de los cambios. Estamos de acuerdo con João do Rio cuando explica el alma de una calle por su historia, sus usos y sus usuarios. En esta búsqueda del origen del alma de una calle, añadimos la importancia de las actividades que se desarrollan en ellas, así como de la influencia de sus características físicas.

En el verano de 2012 hice una etnografía en algunos tramos de la calle llamada Avenida Siete de Setiembre9, situada en el centro histórico de la ciudad de Salvador, capital del Estado de Bahía, en el noreste de Brasil. El objetivo era entender el alma de la calle y de hecho encontré varias almas diferentes en cada trecho de esa larga calle ${ }^{10}$. Cita- ré dos tramos en los cuales queda claro que el alma de la calle adviene de sus actividades y sus características físicas.

En un tramo de la avenida (un conjunto de tres cuadras pequeñas llamadas Calle del Fuerte) encontramos personas caminando lenta y tranquilamente, que se detienen en medio de la calle al encontrar conocidos, personas que saludan a vendedores, gentes sin miedo alguno de las personas sin hogar que duermen extendidas en sus cajas de cartón. En el turno de la mañana, hasta las 11 horas más o menos, este sector de la calle reúne a transeúntes que van a la panadería a comprar pan, que vuelven del gimnasio o se dirigen a sus respectivos trabajos, a madres que llevan a sus hijos a la escuela. ¿Cómo puede una calle de un concurrido centro comercial de la ciudad tener un alma, digamos, familiar?

Una actividad es esencial para explicar este tipo de alma: la venta de alimentos por los vendedores ambulantes. En la calle encontramos a un vendedor de "beiju" (masa tostada de harina de yuca), vendedores de frijoles verdes, vendedores de verduras, de castañas, de camarones secos, además de un vendedor de queso y dulce de guayaba y algunos vendedores de diversas especias.

9 Normalmente, las avenidas son calles anchas y grandes, pero no es este el caso de la calle Siete de Setiembre, que no obstante esta particularidad fue denominada avenida.

10 Para la descripción de todos los trechos investigados, remito al lector a los artículos "Avenida Sete e seus transeúntes" (parte I) y "Transeuntes e usos da Avenida Sete" (parte II) (Montoya y Carvalho, 2014). 
Por supuesto que las farmacias, panaderías, cafeterías, quioscos de prensa, etc., son también espacios importantes para establecer contactos entre las personas, pero el comercio ambulante de comidas es particularmente especial para promover breves "relaciones familiares", entre compradores y vendedores: ellos y ellas no solo se conocen, se llaman por sus nombres, se saludan, intercambian preguntas cordiales (“¿qué tal?, ¿cómo estás hoy?”), sino que también venden o compran a crédito $y$, cuando el tiempo del cliente lo permite, se sientan para una prosa más larga. El comercio de alimentos convierte a esta calle en un espacio familiar, donde uno se detiene, donde se conversa y no solo se pasa. Este comercio promueve lo que Isaac Joseph llamó de la "experiencia de excedente de sociabilidad" (Joseph, 2002, p. 14).

¿Por qué este tipo de vendedores se instala en este tramo de la calle y no en otros? Vimos que la historia marca a las calles: de hecho, esta calle fue una feria en el pasado y, luego, un lugar donde se vendía pescado. Quedan hoy los vendedores citados. Pero más allá de la memoria que el espacio conserva, la calle tiene ciertas características físicas que le permiten acoger a ambulantes de víveres, que hacen que ellos no molesten a los guardias municipales ni a los transeúntes. Se trata de los callejones que se encuentran en ella, y que permiten que los ambulantes se ubiquen ahí, entre la calle y el pasillo.

El vínculo entre las actividades y las características físicas de la calle fue uno de los descubrimientos de la etnografía en las calles del barrio Catumbi (Río de Janeiro), realizada por el equipo coordinado por el arquitecto y antropólogo Nelson dos Santos en la década de 1970. Actividades y espacios se conjugan de formas más complejas de los que solemos pensar:

Hay combinaciones de espacios y actividades en las que los primeros no son sólo formas que albergan un contenido posible sino que también contribuyen a su realización. Del mismo modo, lo que sucede en un lugar no es sólo una esencia vertida en un recipiente vacío; esta esencia se modifica con su forma, que contribuye decisivamente a la conformación y calificación de los ambientes (Santos, 1981,p. 49).

El alma familiar de la que hablamos se encuentra generalmente en las calles de barrio, que tienen menos movimiento, calles donde hay espacio suficiente y donde no falta un pequeño comercio. Estas características hacen posible el establecimiento de relaciones de las que habló Jane Jacobs. En las calles de Catumbi, de acuerdo a la verificación del equipo de Santos, las apropiaciones no tienen necesidad de esconderse en los callejones, pueden ocurrir en las esquinas, incluso en medio de la calle, conformando "puntos" que no incomodan a los usuarios, porque las actividades que se desenvuelven en ellos son de interés público:

Un punto es un espacio en las aceras, en las esquinas o en medio de la calle, que es apropiado por determinadas 
prácticas y por las personas que se dedican a ellas. El ponto do bicho [nombre dado a una lotería clandestina muy popular] es un buen ejemplo de esta forma de apropiación del espacio colectivo (...). El punto se puede conectar al trabajo o al ocio, y es caracterizado por el ejercicio regular de una actividad. Tal actividad tendrá que ser necesariamente de dominio público, sin la cual sería incapaz de crear el punto (Santos, 1981, p. 70).

Sin embargo, no todas las calles son familiares. Hay calles que no cuentan con una historia, gente y lugares donde se puedan desenvolver relaciones familiares. Esto no significa que los usuarios transiten en ella con miradas o gestos blasé. Por el contrario, hay algunas que sin desenvolver relaciones familiares, propician lo contrario de la indiferencia. En este tipo de calles se agudiza el sentido de la vista, aflora la curiosidad, se mira viendo. Como ejemplo de este tipo de calle podemos citar otro tramo de la avenida Siete de Setiembre, que va desde la Casa de Italia a la Plaza de la Piedad. En ella predominan las actividades comerciales, aunque la función residencial también persiste en algunas casas y edificios. Además de las agencias del gobierno (el Instituto Nacional de Seguridad Social, el Ministerio de Trabajo, etc.), de iglesias y bancos, en este tramo se concentra el comercio de electrodomésticos, ópticas, tiendas de ropa, de ropa íntima, de cama, de baño, etc. Todas las personas que circulan en este tramo en horario comercial -funcionarios públicos, empleados bancarios, trabajadores por cuenta propia, amas de casa, estudiantes, profesionales liberales, sacerdotes y monjas- andan mirando las tiendas, las vitrinas, los avisos publicitarios, los anuncios de precios, aun si el objetivo de pasar por la calle no sea el de comprar. En este trecho, los ojos adquieren vida propia. ¿Podría ser esta una característica de toda calle comercial?

No. En muchas - como verificamos en otras partes de la propia avenida Siete- la vista se dirige más al piso o hacia donde se dirigen que a los lados. La primacía de la vista no se explica solo por la oferta de mercaderías. Es preciso también que el ambiente de la calle facilite la soltura de los ojos. En el caso del pasaje en cuestión, una característica física es particularmente importante: en el lugar no hay muchas calles que cortan la avenida, y las pocas que existen no provienen de lugares con mucho movimiento. La calle, en este tramo, parece un corredor: no hay grandes entradas por donde surja un número significativo de personas, o callejones donde los ambulantes puedan instalarse o muchas calles para cruzar. De modo que para la mayoría de los transeúntes, la calle funciona como un pasillo tranquilo, en el que están expuestas las mercaderías y es posible una tranquilidad mínima necesaria para caminar $\mathrm{y}$, al mismo tiempo, permanecer mirando maniquíes. 


\section{Palabras finales sobre calle y calles}

Vimos en la sección anterior cómo João do Rio supo ver el alma de las calles. Constatamos también cómo algunas investigaciones etnográficas -cité la de Nelson dos Santos en Catumbi y la mía en la avenida Siete- se proponen abiertamente descubrir esta alma. Las etnografías de las calles reales difícilmente confirman las imágenes que vimos en la primera sección de este artículo. Por el contrario, lo que es sorprendente es la gran posibilidad de encontrar calles con alma familiar.

En sus estudios de la década de 1970, Michel de Certeau ya intuyó cómo el seguimiento de la vida cotidiana de una calle debería "conducir a una teoría de las prácticas diarias, del espacio vivido y de una inquietante familiaridad [cursivas mías] de la ciudad" (Certeau, 2009, p. 163). Recientemente, las pesquisas etnográficas urbanas del antropólogo Michel Agier lo condujeron también a afirmar la familiaridad de la ciudad vivida: "Cada uno y cada una traza sus recorridos familiares en la ciudad... independiente de las formas materiales que tomen, esta dimensión familiar de la ciudad [cursivas mías] es una parte esencial de la vida citadina, es ella la que permite el anclaje mínimo de cada uno" (Agier, 1999, p. 55, traducción de la autora).

En consecuencia, las etnografías urbanas están mostrando que la calle no es solo tránsito, multitud, anonimato, actitudes blasé, o vías de locomoción; las calles son lugares de relaciones y contactos que muchas veces suelen ser bastante familiares.

Las etnografías urbanas -investigaciones empíricas y detalladas, que de manera insistente y metódica ven y oyen las especificidades de las calles ${ }^{11}$ nos permiten también relativizar las grandes narrativas de intelectuales que, a partir de una perspectiva teórica, leyeron la calle en el Brasil como que es el dominio de la impersonalidad y de la formalidad, el local de la indiferencia y el descuido. En contraste con la mirada "de fuera y de lejos", la investigación etnográfica -que mira "de cerca y de dentro" (Magnani, 2002)- logra entender que las calles no son espacios que pueden ser calificados sin llevar en consideración las actividades específicas que en ellas se desarrollan, los actores que los transitan y la historia que los marca. Como bien escribió Nelson dos Santos,

Sólo en mapas, planos y planes, las calles pueden ser vistas apenas como

11 Para más detalles sobre el método etnográfico remito al lector a mi artículo “O que é fazer etnografia para os antropólogos" (Montoya, 2012); y para una mayor información acerca de la necesidad de desarrollar una mirada disciplinada para entender las calles de las grandes ciudades, véase mi artículo "Olhar a cidade. Contribuições para a etnografia dos espaços urbanos" (Montoya, 2013). 
medio de circulación entre dos puntos distantes (...), una calle es un universo de múltiples eventos y relaciones (...), son lugares en los que ocurre la vida social al ritmo del flujo constante que todo lo mezcla (Santos, 1981, p. 24).

Es necesario, pues, descender a las calles, lanzarse a las calles para aprehender la vida social en ellas. El mirar las calles desde arriba -a partir de una visión macro y estructural- contiene el mismo problema que Michel de Certeau detectó en aquellos que querían entender la ciudad a partir de la vista panorámica ofrecida desde el piso 110 del World Trade Center. $\mathrm{Su}$ resultado es un desconocimiento de las prácticas que solo son visibles desde abajo, donde se encuentran los practicantes de la ciudad: "La ciudadpanorama es un simulacro 'teórico' (es decir, visual); en fin, un cuadro cuyo supuesto es el olvido y el desconocimiento de las prácticas [cursivas mías]" (Certeau, 2009, p. 159). ¿Cómo entender las calles sin ver a sus practicantes/transeúntes, sus usos, sus actividades, su memoria? ¿Cómo entender las calles sin ver a sus practicantes/ocupantes, las actividades que inventan o reinventan, su sumisión o su ajuste de cuentas con la historia, y sin llevar en consideración las lecturas que ellos hacen de las características del espacio? Cuando seguimos las prácticas y los practicantes del espacio, dejamos de hablar de la calle y pasamos a hablar de las calles.

¿Cómo queda el concepto de calle en el singular de la palabra? No esta- mos proponiendo la desaparición del término en singular. Proponemos sí, que los conceptos sean el fruto de la diversidad real, y no borren o extingan esa enorme diversidad existente. Al referirse al concepto de sociedad, el antropólogo Viveiros de Castro escribió sobre esta necesidad:

Continuamos buscando conceptos capaces de iluminar las diferencias entre las sociedades, única vía abierta a la antropología para lograr un punto de vista verdaderamente universal, o mejor, "multiversal"; es decir, un punto de vista capaz de fecundar y desarrollar la diferencia (Viveiros de Castro, 2002, p. 316).

No partamos, pues, de una definición previa de la calle, descubramos las diversas calles que existen en una ciudad, aceptemos la aventura de descender hasta ellas, de caer en ellas, de sentarnos y caminar en ellas para ver cómo son efectivamente practicadas, para luego nombrarlas o adjetivarlas y, solo después, crear un concepto "multiversal" de calle.

\section{Referencias}

Agier, M. (1999). L'Invention de la ville. Banlieus, townships, invasions et favelas. París: Éditions des Archives Contemporaines.

Berman, M. (1989). Tudo que é sólido desmancha no ar. A aventura da modernidade. São Paulo: Companhia das Letras. 
Buarque de Holanda, S. (1994). Raízes do Brasil. (26. ${ }^{a}$ ed.). Río de Janeiro: José Olympio.

Certeau, M. de (2009). A invenção do cotidiano. Volumen 1. Artes de Fazer. (16. ${ }^{a}$ ed.). Petrópolis: Vozes.

Christlieb, P. F. (2004). El espíritu de la calle: psicología política de la cultura cotidiana. Barcelona: Anthropos.

Da Matta, R. (1985). A casa e a rua. Espaço, cidadania, mulher e morte no Brasil. São Paulo: Brasiliense.

Da Matta, R. (2004). O Brasil como morada. Apresentação. En: G. Freyre. Sobrados e mucambos. Decadência do patriarcado rural e desenvolvimento do urbano. (15. ${ }^{a}$ ed.). São Paulo: Global.

Frehse, F. (2005). O tempo das ruas na São Paulo de fins do império. São Paulo: Edusp.

Frehse, F. (2011). Ô da rua. O transeunte e o advento da modernidade. São Paulo: Edusp.

Freyre, G. (1994). Casa-Grande \& senzala. (29. ${ }^{a}$ ed.). Río de Janeiro: Record.

Freyre, G. (2004). Sobrados e mucambos. Decadência do patriarcado rural e desenvolvimento do urbano. (15. ${ }^{\mathrm{a}}$ ed.). São Paulo: Global.

Jacobs, J. (1973). Muerte y vida de las grandes ciudades. Madrid: Península.

Joly, M. (1994). Introdução a análise da imagem. (4. ${ }^{a}$ ed.). Campinas: Papirus.

Joseph, I. (2002). El transeúnte y el espacio urbano: sobre la dispersión y el espacio urbano. Barcelona: Gedisa.

Le Corbusier (1962). La ciudad del futuro. Buenos Aires: Ediciones Infinito.
Magnani, J. G. (1996). Quando o campo é a cidade: fazendo antropologia na metrópole. En J. G. Magnani y L. de L. Torres (Orgs.). Na metrópole: textos de antropologia urbana. São Paulo: Edusp/Fapesp.

Magnani, J. G. (2002). De perto e de dentro: notas para uma etnografia urbana. Revista Brasileira de Ciências Sociais, 49(17).

Marx, M. (1989). Nosso chão: do sagrado ao profano. São Paulo: Edusp.

Montoya Uriarte, U. (2011). Cronistas da cidade e cultura urbana em inícios do século XX. Os costumbristas de Lima e João do Rio. PontoUrbe, 9. Recuperado de http://pontourbe. revues.org/254

Montoya Uriarte, U. (2012). O que é fazer etnografia para os antropólogos. PontoUrbe, 11. Recuperado de http://pontourbe.revues.org/300

Montoya Uriarte, U. (2013). Olhar a cidade. Contribuições para a etnografia dos espaços urbanos. PontoUrbe, 13. Recuperado de http:// pontourbe.revues.org/774

Montoya Uriarte, U. y Carvalho, M. J. (2014). Avenida Sete e seus transeuntes (parte I). Transeuntes e usos da Avenida Sete (parte II). En U. Montoya Uriarte y M. J. Carvalho (Orgs.), Panoramas urbanos. Usar, viver e construir Salvador. Salvador: Edufba.

Poe, E. Alan. (1840). O homem da multidão. Londres. Recuperado de www. ufrgs.br/proin/versao_2/textos/homem.rtf 
Río, J. do. (2008). A alma encantadora das ruas. Org. de Raul Antelo. São Paulo: Companhia das Letras.

Santos, C. N. dos et al. (1981). Quando a rua vira casa. A apropriação de espaços de uso coletivo em um centro de bairro. (2. ${ }^{a}$ ed., revisada y actualizada). Río de Janeiro: Ibam/Finep.

Simmel, G. (1967). A metrópole e a vida mental. En O. Velho (Org.),
O fenômeno urbano. Río de Janeiro: Jorge Zahar.

Viveiros de Castro, E. (2002) O conceito de sociedade em antropologia. En E. Viveiros de Castro, $A$ inconstância da alma selvagem e outros ensaios de antropologia. São Paulo: Cosac \& Naify. 